\title{
Cows, Condos, or Neither: What's Best for Rangeland Ecosystems?
}

\section{Find out how plant communities vary across ranches, ranchettes, and na- ture reserves in one Colorado watershed.}

\author{
By Jeremy D. Maestas, Richard L. Knight, and Wendell C. Gilgert
}

$\mathrm{M}$ uch debate is heard on the range about the role of cattle ranching in the western U.S. Fueled by rural population growth in this region, a "New West" is emerging in which many private ranchlands are being divided into low-density residential developments, commonly referred to as "ranchettes."

Subsequently, this settlement pattern and its residents are changing the West's character and economy. The land-use conversion from ranching to exurban development has caught the attention of conservationists and has generated heated discussion about whether cows are better for rangeland ecosystems than condos (see Wuerthner 1994, Brown and McDonald 1995, Knight et al. 1995). Many nongovernmental conservation organizations are taking the side of ranchers by working with them to keep ranchlands from being developed, but they are doing so with virtually no scientific evidence to support their actions.

Of course, the dichotomy of cows versus condos is too simplistic. Even though exurban development seems to be the most common alternative for private ranches that are sold today in the West, another landuse option is designation as a nature reserve. Nature reserves are lands that are permanently kept out of commercial or residential development and where uses such as grazing, mining, and logging are restricted or prohibited. Examples of this land use include federal wilderness areas, national parks and wildlife refuges, state parks and wildlife areas, and private reserves.

Some environmentalists purport that the only way to preserve healthy rangeland ecosystems is to get land out of the hands of ranchers and into some type of nature reserve. Until now, science has had a minimal role in this discussion. Here, we provide a summary of the results of a study that compared plant communities across nature reserves, ranches, and exurban developments in a rural northern Colorado watershed.

\section{Changes In The Mountain West}

The region of the United States known as the Mountain West (Arizona, Colorado, Idaho, Montana,
Nevada, New Mexico, Utah, and Wyoming) is currently undergoing a human population boom and land-use conversion that rivals any in its history. In fact, five of the

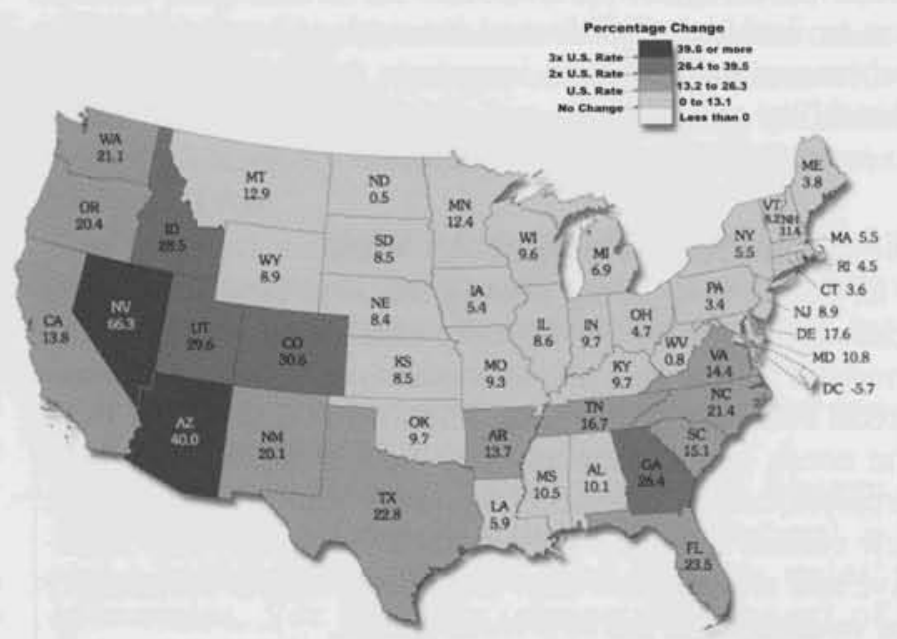

Fig. 1. Percentage change in resident population in the U.S. between 1990 and 2000. Source: adapted from the U.S. Census Bureau

(<http://blue.census.gov/population/www/cen2000/respop.html>).

eight states in this region had the fastest population growth rates in the country between 1990 and 2000 (Fig. 1).

Although metropolitan areas such as Denver, Salt Lake City, and Phoenix have accommodated many newcomers, rural areas are actually growing at a faster rate and over a broader area. The USDA Economic Research Service reports that almost $80 \%$ of the land used for residential development in the U.S. between 1994 and 1997 occurred outside of incorporated city limits (see $<$ http://www.ers.usda.gov/publications/aer803>).

Furthermore, the per capita rate of land consumption far exceeds annual population growth rate in this region. For example, whereas population growth rate in Colorado averaged around 3\% yearly from 1960 to 1990 , the annual rate of land conversion to houses averaged $8 \%$ (Sullins et al. 2002). So, concerns about growth are not just about population size, but also about the dispersed 
pattern of settlement residents are choosing.

Driven by a mixture of economic and quality-of-life features, people are moving to the rural parts of a region rich in public lands (Power 1996). In turn, private lands in agriculture are being exchanged for exurban developments as immigrants seek to live where they play, and has resulted in a "New West" characterized by its desire for natural amenities, its service and recreation-based economies, and its retirement communities. In other words, many counties in the rural West are shifting from areas of production to areas of consumption (Shumway and Otterstrom 2001).

Consequently, exurban development has become a principal use of rural land in the Mountain West, joining the traditional major land uses of livestock ranching and nature reserves (Vesterby and Krupa 1997). Although the amount of land being set aside for nature reserves annually is increasing slowly, lands in ranching and exurban development are in a rapid state of flux as ranches are subdivided for rural residences. For example, between 1992 and 1997 in Colorado, 270,000 acres per year were converted from agriculture to other uses such as residential development.

\section{Conservationists Respond}

These alterations of the Mountain West landscape have not gone unnoticed by conservationists. There is a growing concern that the conversion of ranchland to exurban develop-
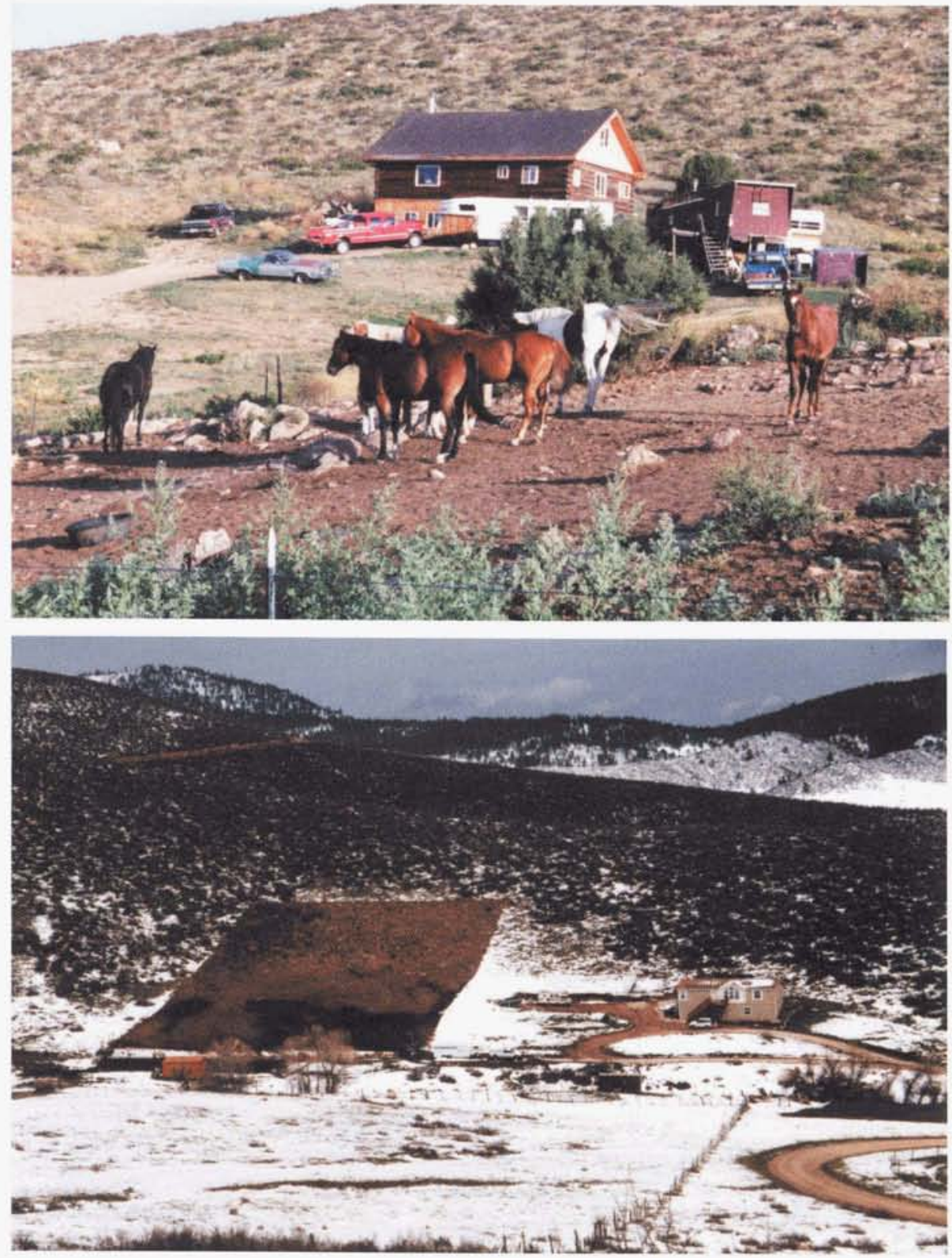

Overgrazed pastures on two ranchettes in northern Colorado. As exurban developments replace ranches across the Mountain West, rangelands may be changing also. Photos by Jeremy Maestas.

ment is altering the region's natural

heritage, although we know of little scientific basis for this notion. Despite this lack of empirical evidence, many nongovernmental conservation organizations are working with ranchers to keep their lands out of development and in ranching because they believe rangeland ecosystems are better maintained on intact ranches (Weeks 2002).

This is being accomplished largely through conservation easements that restrict development rights but often allow continued livestock grazing (Morrisette 2001). Such a strategy has become increasingly popular with The Nature Conservancy, Rocky Mountain Elk
Foundation, and other land trust organizations. In fact, recent statistics indicate that more than 1,200 land trusts nationwide have protected roughly $2,600,000$ acres from future development through conservation easements (see www.lta.org/newsroom/census_summary_data.htm).

Despite its popularity, the use of conservation easements as a strategy to protect rangeland ecosystems has several assumptions that have not been tested. For example, this approach assumes that plant and wildlife communities on ranches are similar to those on nature reserves, or, at the very least, that native plant and wildlife communities are better maintained on ranches than they 


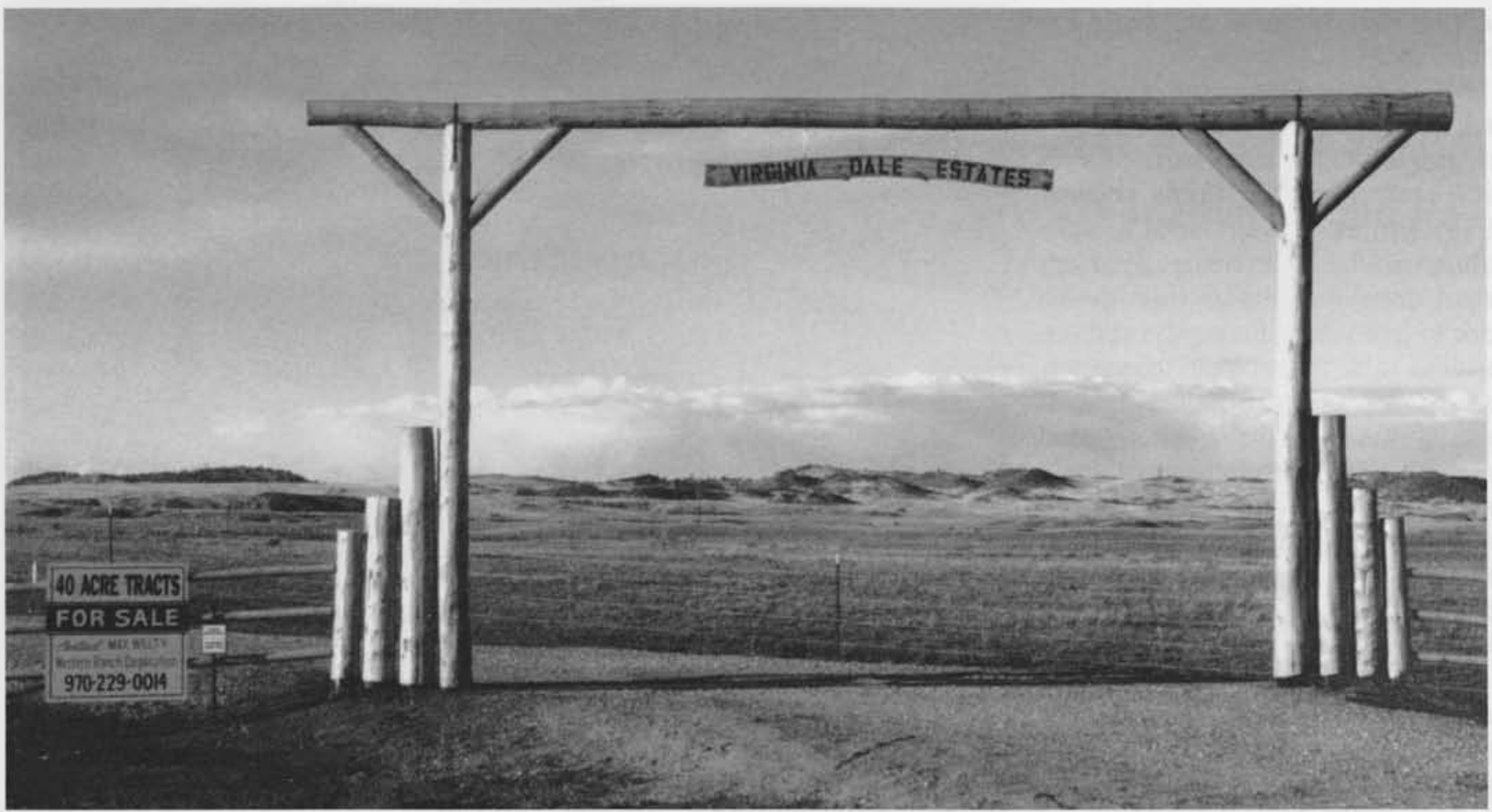

This once working ranch was recently sold and platted for subdivision. Newcomers can now "ranch" 40-acre estates for the right price. Photo by Jeremy Maestas.

would be on exurban developments. This approach is being used even though some environmentalists argue that ranching is the most detrimental land use to native biodiversity and rangeland ecosystems in the West (see Fleischner 1994).

To assess the various assumptions of this new rangeland protection strategy, we conducted a study comparing plant communities across three of the principal land uses in Larimer County, Colorado: nature reserves, livestock ranching, and exurban developments.

\section{Testing Assumptions Of New Conservation Strategy}

We conducted this study in an area encompassing about 50,000 acres in the foothills of the North Fork of the Cache la Poudre River Watershed along the Colorado Front Range of the Rocky Mountains. Our study area is approximately 25 miles northwest of Fort Collins. The land-use matrix of the area is typical of the Mountain West and is composed of private ranchlands, National Forest lands, and state wildlife areas, with some ranchettes perforating the landscape.

Plant communities are dominated by grasses and shrubs, although some trees occur at higher elevations. Common species include needle-and-thread, blue grama, western wheatgrass, cheatgrass, fringed sage, mountain mahogany, skunkbrush sumac, and bitterbrush. Average annual precipitation ranges from $13-18$ inches, with $75 \%$ of it falling between April and September according to the Soil Survey of the Larimer County Area, Colorado.

We selected study sites within this watershed with similar plant community types composed of shrubs (primarily mountain mahogany and bitterbrush) and grasses (mainly needle-and-thread and western wheatgrass), at similar elevations (5,700-7,200 feet), and on similar soil types to reduce natural variability among sites. Study sites ranged in size from 2,500-12,000 acres and included two nature reserves, three ranches, and two exurban developments.

Nature reserves were Colorado Division of Wildlife State Wildlife Areas, whose principal use was outdoor recreation and wildlife protection (no livestock grazing, logging, mining, or water development). For the most part, the two Division of Wildlife properties were ungrazed by livestock for 18 and 33 years prior to our study. However, livestock grazing was used to reduce noxious weeds until 5 and 7 years ago, respectively, on the two sites. Stewardship of these areas was primarily custodial.

Ranches were privately owned, and cattle grazing was managed through deferred-rotation grazing systems. Although specific stocking rates were not obtained, visual inspection of forage utilization indicated that all three ranches had moderate grazing intensities. These ranches have been in livestock production for at least 100 years. 


\section{Native Species Canopy Cover}

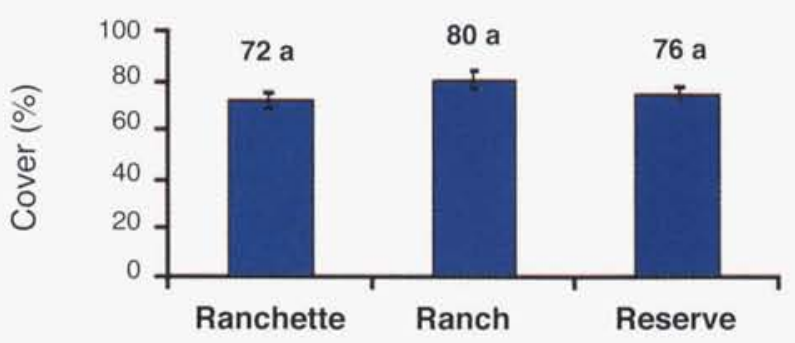

Nonnative Species Canopy Cover

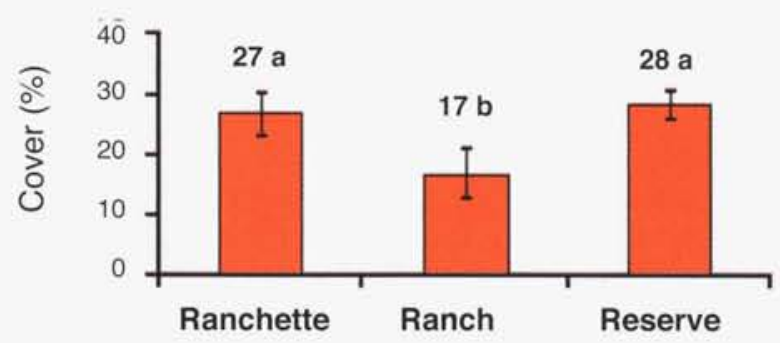

Fig. 2. Average canopy cover $( \pm S E$ ) of native and nonnative plants at each sampling point on lands used for ranchettes, ranches, and nature reserves. Letters next to cover estimates indicate the results of statistical comparisons. Different letters represent statistically significant differences.

Exurban development areas had lots from $35-50$ acres, with ranchettes being used mostly for year-round residences. The average housing density within exurban developments was 1 house per 40 acres, and the average house age was 9 years. These areas began development about 30 years prior to our study and are still undergoing development. The amount of forage utilization on individual ranchette properties varied from no livestock use to intensive grazing.

We randomly selected 23 sampling points within each land use (nature reserve, ranchland, and exurban development) for a total of 69 points, which we used to characterize the plant communities. Points had to be at least 0.2 miles apart and occur on areas with slopes less than $35 \%$. Also, points had to be away from riparian areas, hay meadows, site boundaries, built structures, and roads to reduce confounding variables between points.

At each sampling point, $8 \times 20$-inch Daubenmire microplots were sampled at $33,66,98$ feet away from the point in each of the cardinal directions $(\mathrm{N}, \mathrm{E}, \mathrm{S}, \mathrm{W})$ for a total of 12 microplots per point. A trained plant taxonomist and a recorder documented percentage canopy cover of plant species, as well as percentage bare ground, litter, and rock within each microplot. Sampling was done during the period of peak standing crop in 2001.
After data were collected in the field, species were classified as native or nonnative and average values for species richness, canopy cover, bare ground, rock, and litter were obtained for each sampling point (Maestas et al. 2003).

\section{Evidence From The Plant Communities}

Ranchlands had slightly more native plant species than did nature reserves or exurban developments, with an average of 27 species per sampling point on ranches compared to 24 on each of the other land uses. Though ranches had more native species on average, the canopy cover of native plants did not differ statistically across the land uses (Fig. 2).

Both species richness and canopy cover of nonnative plants, however, were statistically significantly lower on ranches than on the other land uses. Average canopy cover of nonnative species at points sampled on ranches was about $17 \%$ compared to $27 \%$ and $28 \%$ on exurban developments and nature reserves, respectively (Fig. 2). Ranchlands had an average of three nonnative species per point, whereas, nature reserves and exurban developments had an average of five.

Examining the dominant nonnative plant, cheatgrass, we discovered that not only was canopy cover of this species statistically significantly higher on nature reserves $(22 \%)$ and exurban developments $(18 \%)$ than on ranches $(14 \%)$, but also that this species accounted for much of the nonnative species cover on each land use.

A total count of nonnative plant species encountered in each land-use category revealed that there were over twice as many nonnative species found on lands devoted

Total Number of Nonnative Species

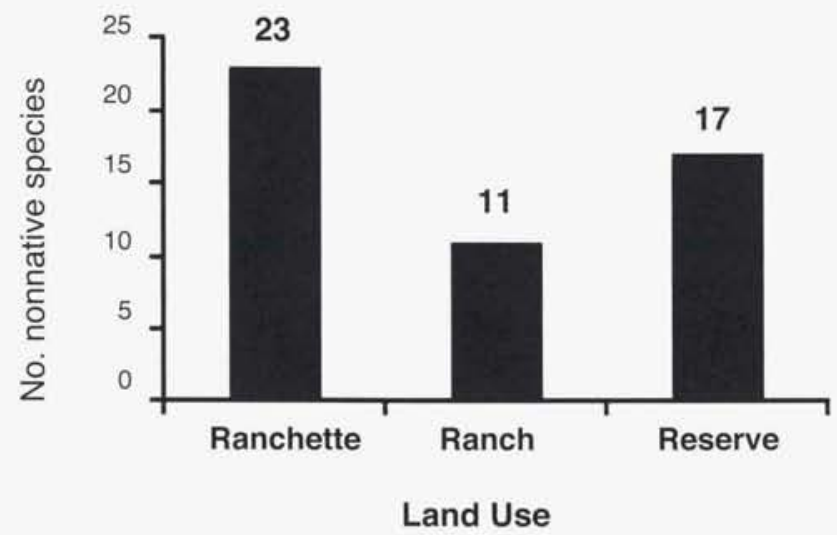

Fig. 3. Total number of nonnative plant species found in each land use category. Eight out of the 23 species seen on ranchettes were unique to that land use, not being detected on ranchlands or nature reserves. 
to exurban development than on lands in ranching (Fig. 3 ). Eight of the 23 nonnative species found on exurban developments were not recorded on either of the other two land uses in the watershed we studied. Two of these eight unique species, spotted knapweed and leafy spurge, are considered noxious weeds in Colorado.

Exurban developments had a higher percentage of bare ground than did nature reserves, with about $30 \%$ of the soil exposed at each point on developments compared to $18 \%$ on reserves. Ranches fell in the middle of the spectrum with about $22 \%$ bare ground. The percentages of litter on ranchlands, nature reserves, and exurban developments were similar across land uses at $35 \%, 31 \%$, and $30 \%$, respectively. As expected, the percentages of rock did not differ significantly among land uses with $10 \%$ rock on both ranchettes and ranches and $8 \%$ rock on nature reserves.

The evolutionary history of herbivory in our watershed may help explain some of the patterns we observed. This region, which is a transitional zone between the shortgrass steppe and the Rocky Mountains, historically supported considerable numbers of bison. Grazing by these animals was an ecological disturbance that produced heterogeneous rangelands composed of plant species that co-evolved with herbivory (Milchunas et al. 1988).

Our results do not contradict findings of earlier studies in the shortgrass steppe showing that these plant communities will more likely have a negative response to the removal of grazing animals rather than a negative response due to grazing by domestic livestock (Milchunas et al. 1990). Even though cattle and bison have somewhat different grazing characteristics, proper management of cattle on ranches in this area may be effective at mimicking natural disturbances in the absence of bison.

Conversely, the removal of grazing by large herbivores on nature reserves or the mismanagement of hobby livestock (i.e., horses, llamas, cattle, etc.) on ranchettes may lead to rangeland degradation, resulting in more weeds and more bare ground.

Human activities occurring on nature reserves and exurban developments are likely to be promoting the relatively high number of nonnative species on these land uses. Humans often serve as accidental or deliberate sources of nonnative species (Mack et al. 2000). Roads and trails are two conspicuous human constructs that are notorious for their role in the spread of nonnative flora (Tyser and Worley 1992).

Besides the obvious disturbances associated with buildings, exurban developments have extensive networks of roads and trails that greatly enhance the likelihood of nonnative species introductions. Mitchell and others (2002) reported the improved road density for one of our exurban developments to be 3.38 miles per section (640 acres) in 1994, which is more than eight times the road density of this area before it was subdivided.
Nature reserves have few roads but the trail systems can be considerable and heavily used by outdoor recreationists such as hikers, mountain bikers, and horseback riders (Knight 2000). The amount of trails and recreational use on Division of Wildlife lands that we studied were not quantified, but personal observation and communication with property managers suggests many unofficial trails have been established and recreational use can be quite heavy in the summer and fall.

Other activities on ranchettes may also be contributing to the spread of nonnative plants. A deliberate source of these plants comes from the landscaping of yards with nonnative and ornamental plants. Although few of these species become invasive, planting with nonnatives alters local plant community dynamics and increases the likelihood of a species spreading onto natural areas. Also, homeowners in exurban developments may be unintentionally aiding in the spread of weeds by feeding hobby livestock non-certified hay and allowing their animals to overgraze native plants, thereby increasing the amount of bare ground and opportunities for weed invasion.

Our study was observational, so some caveats should be acknowledged. Like much of the American West, all of our study sites, including nature reserves and exurban developments, were grazed by livestock prior to their current uses. However, we believe that our sites have been in reserves, ranching, or exurban development long enough to produce the differences we observed in plant communities. Additionally, our results come from a single plant community type in one watershed so inferences should be restricted to our study sites. Further research examining whether the trends we observed hold true for other locales in the Mountain West might prove instructive.

\section{Conservation Strategy Supported, Ranches Do Best}

Are conservation organizations justified in assuming that cows are better for rangeland ecosystems than condos? Ultimately, this may be a question of values rather than science, but if the goal is to maintain native plant communities with less bare ground, results from our study along the Colorado Front Range support this assumption.

Interestingly, the notion that nature reserves are the best way to maintain rangeland ecosystems was not entirely supported by our data. Nature reserves had plant communities that were more similar to those found on ranchettes than on ranches, but nature reserves did have less bare ground than did exurban developments.

Although judging the condition of rangeland ecosystems based on a few plant community characteristics is rudimentary, data from wildlife communities on ranches, ranchettes, and nature reserves concur with our generalizations (Odell and Knight 2001, Maestas et al. 2003). An ex- 
amination of songbird and mammalian predator communities across these rural land uses in our study area revealed that a host of so-called "human-adapted" species, such as the black-billed magpie, European starling, domestic dog, and house cat, had population sizes that were up to 15 times greater on ranchettes than on ranches or nature reserves (Maestas et al. 2002). In Pitkin County, Colorado, Odell and Knight (2001) showed that ranchettes had elevated populations of these human-adapted species and reduced populations of more sensitive species, such as the orange-crowned warbler and red fox.

Ranches and nature reserves, however, can maintain different populations of some species of conservation concern. For example, ranchlands in our study area had more Brewer's sparrows than nature reserves and ranchettes, while reserves had more green-tailed towhees than ranches and ranchettes (Maestas et al. 2003). These studies suggest a change in biodiversity with the subdivision of ranchlands, and differences in habitat conditions between ranches and nature reserves.

\section{Implications For Conservation}

To our knowledge, our study is the first to document and compare plant communities associated with ranches, ranchettes, and nature reserves. We were able to record some trends across these land uses that have implications for rangeland managers and conservationists.

First, nonnative species are likely to become an increasing issue as ranches are subdivided into ranchettes. Because exurban developments are embedded in rural areas, often adjacent to public lands and ranchlands, they may be supplying propagules of nonnative plants to surrounding lands. At the site scale, ranch and public land managers near developments should monitor their lands to locate and treat establishing nonnative plants before they have a chance to spread.

At the landscape scale, managers must recognize that exurban developments may be serving as regional sources of nonnative species. This implies that they must actively work with homeowner's associations in order to prevent the spread of weeds, both for the sake of the developments and nearby ranches and natural areas.

Second, in our study, ungrazed nature reserves did not maintain native plant community composition as effectively as grazed ranchlands did. This supports evidence from comprehensive studies of grazing that demonstrate that removing cattle from landscapes will not necessarily lead to restored rangeland ecosystems (Curtin 2002). Nature reserves are often assumed to serve as a benchmark of natural conditions and as strongholds for species of conservation concern, but when historic disturbance processes such as grazing are lacking, sites may not function in this capacity.

These areas may lack adequate stewardship to control nonnative plant species through the use of fire, grazing, and herbicides. Furthermore, outdoor recreational use both on and off trails should be monitored and regulated as it may be contributing to the spread of invasive species.

Management of nature reserves for native rangeland conditions will require active stewardship, such as the restoration of historic ecological processes, and not simply "hands-off" management.

Nongovernmental conservation organizations that work with ranchers to protect rangeland ecosystems in the foothills of the Colorado Front Range appear to be doing the right thing. Private ranchlands are critically important for biodiversity and rangeland conservation, especially considering that private landowners hold most of the highly productive, low elevation land and that most nature reserves occur on relatively unproductive, high elevation sites (Scott et al. 2001).

These facts, combined with the results from our study, suggest that conservationists will not be able to sustain native rangeland ecosystems in the Mountain West by relying solely on nature reserves. Future conservation efforts to protect rangelands will require a greater focus on private lands, conservation easements that permit active management, and an ability to work effectively across administrative boundaries (Knight and Clark 1998).

Authors are, respectively, Wildlife Biologist, USDA-NRCS, Provo, Utah 84606,E-mail: jeremy.maestas@ut.usda.gov; Professor of Wildlife Biology, Colorado State University, Fort Collins, Colo. 80523; and Faculty Affliate (from the USDA-NRCS Wildlife Habitat Management Institute), Department of Fishery and Wildlife Biology, Colorado State University, Fort Collins, Colo. 80523.

This paper was peer-reviewed. We thank Wayne Leininger for assisting with the design of this study and for reviewing this manuscript, and one anonymous reviewer for their helpful suggestions. Also, we thank Steve Thomas for providing expertise and assistance with the plant sampling. Finally, we are indebted to the USDA-NRCS Wildlife Habitat Management Institute and the Western Center for Integrated Resource Management at Colorado State University for funding this research.

\section{References}

Brown, J. H. and W. McDonald. 1995. Livestock grazing and conservation on Southwestern rangelands. Conserv. Biol. 9:1644-1647.

Curtin, C. G. 2002. Livestock grazing, rest, and restoration in arid landscapes. Conserv. Biol. 16:840-842.

Fleischner, T. L. 1994. Ecological costs of livestock grazing in western North America. Conserv. Biol. 8:629-644.

Knight, R. L. 2000. Forest fragmentation and outdoor recreation in the Southern Rocky Mountains, p. 135-153. In: R. L. Knight, F. W. Smith, S. W. Buskirk, W. H. Romme, and W. L. Baker (eds.), Forest fragmentation in the Southern Rocky Mountains. Univ. Press Colo., Boulder, Colo.

Knight, R. L., G. N. Wallace, and W. E. Riebsame. 1995. Ranching the view: subdivisions versus agriculture. Conserv. Biol. $9: 459-461$. 
Knight, R. L. and T. W. Clark. 1998. Boundaries between public and private lands: defining obstacles, finding solutions, $p$ 175-191. In: R. L. Knight and P. B. Landres (eds.), Stewardship across boundaries. Island Press, Washington, D.C.

Mack, R. N., D. Simberloff, W. M. Lonsdale, H. Evans, M. Clout, and F. A. Bazzaz. 2000. Biotic invasions: causes, epidemiology, global consequences, and control. Ecol. Applic. 10:689-710.

Maestas, J. D., R.L. Knight, and W.C. Gilgert. 2003. Biodiversity across a rural land-use gradient. Conserv. Biol. In Press.

Milchunas, D. G., O. E. Sala, and W. K. Lauenroth. 1988. A generalized model of the effects of grazing by large herbivores on grassland community structure. Amer. Natur. 132:87-106.

Milchunas, D. G., W. K. Lawenroth, P. L. Chapman, and M. K. Kazempour. 1990. Community attributes along a perturbation gradient in a shortgrass steppe. J. Veg. Sci. 1:375-384.

Mitchell, J. E., R. L. Knight, and R. J. Camp. 2002. Landscape attributes of subdivided ranches. Rangelands 24:3-9.

Morrisette, P. M. 2001. Conservation easements and the public good: preserving the environment on private lands. Natural Resources Jour. 41:373-426.

Odell, E. A. and R. L. Knight. 2001. Songbird and medium-sized mammal communities associated with exurban development in Pitkin County, Colorado. Conserv. Biol. 15:1143-1150.

Power, T. M. 1996. Lost landscapes and failed eeonomies. Island Press, Washington, D.C.
Scott, J. M., F. W. Davis, R. G. McGhie, R. G. Wright, C. Groves, and J. Estes. 2001. Nature reserves: do they capture the full range of America's biological diversity? Ecol. Applic. 11:999-1007.

Shumway, J. M. and S. M. Otterstrom. 2001. Spatial patterns of migration and income change in the Mountain West: the dominance of service-based, amenity-rich counties. Prof. Geographer $53: 492-502$.

Sullins, M. J., D. T. Theobald, J. R. Jones, and L. M. Burgess. 2002. Lay of the land: ranch land and ranching, p. 25-31. In: R. L. Knight, W. C. Gilgert, and E. Marston (eds.), Ranching west of the $100^{\text {th }}$ meridian. Island Press, Washington, D.C.

Tyser, R. W. and C. A. Worley. 1992. Alien flora in grasslands adjacent to road and trail corridors in glacier National Park, Montana (U.S.A.). Conserv. Biol. 6:253-262.

Vesterby, M. and K. S. Krupa. 1997. Major uses of land in the United States, 1997. U.S. Dept. Agr., Econ. Res. Serv. Statistical Bulletin No. 973.

Weeks, W. W. 2002. Cloudy sky over the range: whose home and why it matters, p. 219-231. In: R. L. Knight, W. C. Gilgert, and E. Marston (eds): Ranching west of the $100^{\text {th }}$ meridian. Island Press, Washington, D.C.

Wuerthner, G. 1994. Subdivisions versus agriculture. Conserv. Biol. 8:905-908. 